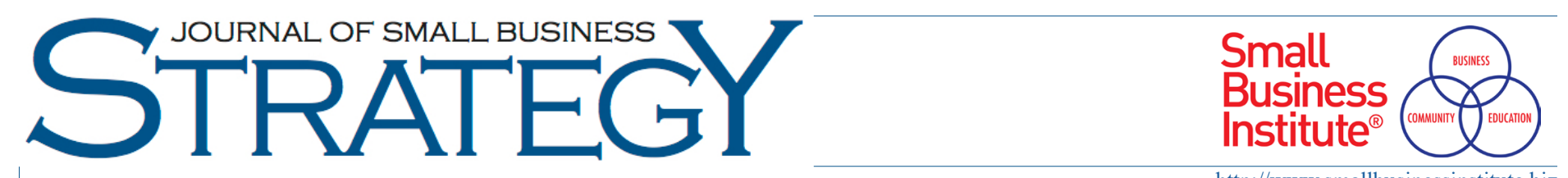

http://www.smallbusinessinstitute.biz

\title{
Financial preferences of listed SMEs in India: An empirical study
}

\author{
Sushma Verma ${ }^{1}$, Samik Shome ${ }^{2}$, Aakruti Patel ${ }^{3}$ \\ ${ }^{1}$ Vivekanand Education Society's, Institute of Management Studies and Research, Hashu Advani Memorial Complex, $495 / 497$ Collector's \\ Colony, Chembur, Mumbai, India, sushma.verma@ves.ac.in \\ ${ }^{2}$ Corresponding Author, Institute of Management, Nirma University, Sarkhej - Gandhinagar Highway, Gota, Ahmedabad, India, samik@, \\ nirmauni.ac.in \\ ${ }^{3}$ Institute of Management, Nirma University, Sarkhej - Gandhinagar Highway, Gota, Ahmedabad, India, aakruti@nirmauni.ac.in
}

Keywords:

Small and medium enterprises, NSE emerge exchange, Panel data regression, Pecking order theory (POT), Trade-off theory (TOT)

\begin{abstract}
A B S T R A C T
Small and Medium-sized Enterprises (SMEs) play a very significant role in boosting sustainable economic growth and development of any country. The present study examines various firm-specific determinants that have an impact on the financing choice of the listed Indian SMEs. It also studied the financing practices of the listed SMEs in India and tried to find out if their financing pattern follows the established theories of Corporate Finance. The study selected 113 SMEs listed on the NSE Emerge Exchange for the period between 2014 and 2018. To examine the problem, empirical analysis is done with the help of panel data regression. The study finds that for meeting financial requirements of listed SMEs, they prefer current liabilities first, then total reserves, thereafter short-term borrowings and lastly the long-term borrowings. Among the independent variables chosen based on an extensive literature survey, most of them are statistically significant but are depicting lower explanatory power. Hence, it leads to the possibility of some other firm-specific factors or macroeconomic factors being more relevant in deciding the listed firm's financing choices. The study concludes that no single theory like Pecking Order Theory (POT) or Trade-Off Theory (TOT) can explain the financing behaviour of listed SMEs completely. It contributes to the extant literature on listed SMEs by attempting to examine the impact of listing on the financing patterns of the SMEs.
\end{abstract}

\section{Introduction}

Small and Medium-sized Enterprises (SMEs) have been globally recognized for promoting sustainable economic growth and development across nations (Ariyo, 2000; Srinivas, 2013). SMEs are defined as a distinct category of firms which are quite different from large companies. Capital constrains, limited managerial expertise, lack of information and other intangible assets are much more in SMEs as compared to large companies (Hollenstein, 2005; Pradhan \& Sahu, 2008). However, SMEs have greater operational flexibility, faster decision making and also niche business strategy when compared to large companies (Zucchella \& Palamara, 2006). They are considered the growth engines of any economy for their contribution to industrial production and exports (Asare, 2014). SMEs' contribution in poverty alleviation is also very crucial considering their potential to create employment opportunities (Green et al., 2006). India is also of no exception to this phenomenon.

Journal of Small Business Strategy

2021, Vol. 31, No. 03, 88-101

ISSN: 1081-8510 (Print) 2380-1751 (Online)

CCopyright 2021 Small Business Institute ${ }^{\circledR}$
With more than 63.4 million SMEs all over the country, it employs more than 120 million people. SMEs in the manufacturing sector alone produce more than 6,000 different types of products and account for approximately $45 \%$ of the total industrial production in India. Similarly, their total contribution to the service sector is around $31 \%$. As of now in India, SMEs are contributing approximately $29 \%$ to India's GDP and 49\% in country's export.

Like any other organization, it is important for SMEs also to have the availability of finance and access to various financing sources on suitable terms and conditions. This is vital for growth and development of SMEs (Osano \& Languitone, 2016; Shikumo \& Mwangi, 2016). However, there is a substantial number of existing literature identifying the financial issues faced by SME sector both in developed as well as developing countries (Beck et al. 2011; Jagoda \& Herath, 2010). SMEs in many cases are not able to keep pace with dynamic technological innovation and are often found using obsolete technology because of the fund constraints (Abdulsaleh, 2015; Yoshino \& Taghizadeh-Hesary, 2018). OECD report (2016) also states that many SMEs are facing credit constraints though there is an improvement in SME

APA Citation Information: Verma, S., Shome, S., \& Patel, A. (2021). Financial preferences of listed SMEs in India: An empirical study. Journal of Small Business Strategy, 31(3), 88-101. 
lending. Reasons like lack of transparency in book-keeping and non-availability of audited financial statements many a time act as a hindrance in the way of bank financing (Liu $\& \mathrm{Yu}, 2008)$. As a result of these drawbacks, the banks become cautious in their lending which often leads to financial crunches for SMEs. In fact, this inability of SMEs to access funds from banks and financial institutions is recognized as one of the major factors coming in the way of their growth and expansion and threatening their existence (Abe et al., 2015; Adeyele, 2018). In India, SMEs receive approximately $16 \%$ of the total bank credit.-

Considering the significance of SMEs for overall inclusive growth, Government of India is taking several steps to promote SME growth by attempting to increase the credit availability to this sector. Reserve Bank of India (RBI) has mandated the scheduled public sector banks for doubling the credit flow for them. RBI has also included the SME sector in priority lending category. The government has also established exclusive exchanges for SME on Bombay Stock Exchange (BSE) and National Stock Exchange (NSE). It has also started the promotion of venture capital fund available through public sector banks and also through various developmental financial institutions.

According to Stevenson and Botzung (2012), SMEs rely on informal sources and self-financing for approximately $78 \%$ of its financing needs. The remaining $22 \%$ of funding needs are met by banks and NBFCs. This dependence of SMEs on informal sources of finance may be due to the limitation of formal lenders to lend to SMEs. Several reasons have been identified for limited funding from banks and NBFCs. One of the reasons, widely recognized in academic literature, is poor record keeping and non-availability of audited financial statements (Liu \& Yu, 2008; Storey, 1994). Other reasons include information asymmetries, high transaction cost, institutional factors and, many a time, poor project quality (Vasilescu, 2014). SMEs are perceived to be high risk lending propositions by lenders, and because of this, very few of them are able to access finance from formal sources (Ambrose, 2012). Within emerging and developing economies, many a time, prevailing regulations are also very rigid to accommodate the financial needs of small firms (Lucey et al., 2016). The Securities and Exchange Board of India (SEBI) issued guidelines in 2010 stating that separate exchange for SMEs are to be set up to provide them with an efficient and transparent platform for raising equity financing. NSE Emerge is the exclusive SME platform launched by National Stock Exchange of India. It is a marketplace that brings together the investors and evolving business houses registered in India. Now, considering the listing requirements, NSE Emerge requires the track record of the company in terms of its financial statements for a minimum of three years and positive Earnings Before Depreciation and Tax (EBDT) in the preceding two years. It is expected that information asymmetry of listed firms should come down. This should logically lead to a relatively easy access to debt finance for listed SMEs as compared to non-listed ones, resulting in a changed financing pattern.

In view of the above discussion, the purpose of this paper is to study the financing practices and trends of listed Indian SMEs. The research objectives of this study are: (a) to find out the current financing trend of listed SMEs; (b) to examine the effect of firm-specific factors of the listed SMEs on their financing decision; and (c) to assess if the financing choice of listed SMEs are following the established Corporate Finance theories (Trade-Off Theory and Pecking Order Theory). This study can help SMEs in making a decision about listing. It can also assist policy makers by providing them with a detailed understanding of the financing preferences of SMEs in framing appropriate policies for improving the financing situation in India.

The existing literature on financing decisions clearly shows the dominance of large firm-specific studies (Chakaroborty, 2010; Handoo \& Sharma, 2014; Rajan \& Zingales, 1995). Results of these studies cannot be generalized for SMEs because of the fundamental difference in their organization (Bas et al., 2009). There is limited research in the field of SME financing despite the growing interest of researchers in this particular field. This study is different from the previous studies as it tries to analyse the impact of listing on the financing choices of SMEs.

This paper is organized into the following sections: Review of Literature describes the existing theoretical and empirical literature on SME financing. The Method section discusses, in detail, the research methodology employed. Findings of the study along with its analysis is being done in Analysis and Results. Discussion and hypotheses validated are in Discussion and Validation of Hypotheses. Identification of the limitations of the study and its future scope is presented in Limitations and Future Scope followed by Concluding Remarks.

\section{Review of Literature}

Since the 1950s, capital structure decisions have become the focus area of researchers in the field of finance. It all started with Modigliani and Miller's (1958) landmark 'Irrelevance Theory' highlighting the irrelevance of capital structure in a company's valuation. It means that a firm's value is not affected by any change in financing decisions. The major limitation of this theory is its assumptions of a perfect capital market, which is not an economic reality. This theory was revised in 1963, and it stated that capital 
structure does affect the company's valuation when tax benefit of the interest component of debt is taken into consideration. After this, there has been several remarkable studies in the field of capital structure leading to the development of a few path-breaking theories like Trade-Off Theory (TOT), Pecking Order Theory (POT), Agency Cost Theory (ACT) and Market Timing Theory (MTT) among others which were based on set of relatively more realistic assumptions.

The two rival theories, in literature, are the TOT by Kraus \& Litzenberger (1973) and POT by Myers (1984). TOT focuses on the concept of optimal capital structure. As per TOT, optimum capital structure, which has just the right or optimum amount of debt, can be achieved by balancing the tax benefit of debt with the cost of financial distress. POT does not believe in the concept of optimum capital structure. As per this theory, there is a particular order of financing preferred by the managers. Internal sources of funds are preferred to external sources and within external sources of funds, debt is preferred to equity. ACT, proposed by Jensen \& Meckling (1976), is based on the concept of agency problem. It refers to the conflict of interest between managers and shareholders and also between the shareholders and lenders. Another theory proposed by Baker and Wrugler in 2002 in the field of capital structure planning is MTT, which believes in the role of timing of the market for debt or equity issues.

TOT, though considered to be the mainstream theory of capital structure, could not explain the prevailing corporate behaviour at several instances. Pecking order hypothesis as an alternative could explain some of the observed patterns in corporate financing. However, in existing literature there has been mixed evidence about applicability of these two theories. As per Datta \& Agarwal (2009), internal funding is more significant for Indian companies confirming POT, but they also indicated the applicability of TOT in a few instances.

Following these theoretical developments, several studies have been conducted to identify various factors affecting the financing decisions of the firms. As per Titman \& Wessels (1988), based on their study of US firms, size, profitability and growth are some of the important factors that have a bearing on the financing choices of the firms. Graham \& Harvey (2001), based on their study on US and Canadian firms, garnered moderate support for the concept of Target Debt Ratio. This ratio is set by the management or lenders to ensure that the business is not highly leveraged. Bhaduri (2002) deduced that the growth, cash flows, and size are some of the prominent factors influencing the capital structure planning in Indian firms. Fauzi et al. (2013), based on their study on 79 firms in New Zealand over a period of four years from 2007 to 2011, inferred that firm size significantly influences the choice of financing source. According to them, large firms in terms of market capitalization employ more long-term debt. Singhania \& Seth (2010) established a negative correlation between leverage of a firm and its growth and liquidity and a positive correlation between leverage and firm size. Khan (2010) shows a positive correlation between debt ratio, tangibility and firm size and negative correlation between leverage and profitability. Similarly, Odit \& Gobardhun (2011) observed a significant difference in the financing choices of large firms and SMEs. Small firms were found to depend more on short-term borrowings as compared to large sized firms.

Various studies have also been conducted to understand the reasons behind the financing choices of SMEs. Several researchers have empirically concluded that TOT is unable to explain SME financing patterns in both developed as well as developing countries (Klapper et al., 2006; Watson \& Wilson, 2002). Kremp et al. (1999) conducted a comparative study on 15,000 French and 9,000 German SMEs, and Benito (2003) conducted a similar study on SMEs in the UK and Spain and concluded that SMEs follow POT of financing. Sanchez-Vidal \& Martin-Ugedo (2005) studied Spanish SMEs, and Daskalakis \& Psillaki (2008) studied SMEs in France and Greece and concluded the same. However, there are several studies indicating the allegiance to the opposite phenomenon. As per Wu et al. (2008), POT could only partially explain SMEs' financing patterns. Yartey (2011), on the basis of their study on SMEs of Ghana, highlighted the greater usage of external debt as compared to internal sources of funds. Odit \& Gobardhun (2011) studied the SMEs in Mauritius and stated that SMEs were observed to be following asset matching principle; that is, long-term debt was used to finance long-term assets, and short-term debt was used to finance short-term assets. Michaelas et al. (1999) studied 3,500 SMEs of the UK and showed that the size and future growth prospects influence the quantum of debt for SMEs.

There are several studies conducted on Indian SMEs also. De (2010) highlighted the problems faced by Indian SMEs in arranging for short as well as long-term finance. Love \& Peria (2005) studied the financing pattern of SMEs in India from 1994 to 2003 by comparing it with large firms. Dogra \& Gupta (2009), showed that the age, level of competition, and quantum of capital investment are some of the important factors that have a bearing on financing choices of SMEs in India. They also concluded that Indian SMEs rely more on internal funds and less on borrowed money. Srinivas (2013) conducted a study on SMEs from 2007 to 2011 and concluded that they use more owned funds than borrowed funds. As per Kulkarni \& Chirputkar (2014), the listing of SMEs should promote fundraising. Kumar \& Rao 
(2016) studied the financing pattern of SMEs for a period between 2006 and 2013 and observed that SMEs rely more on short-term debt. Rao et al. (2018) empirically analysed a few factors which may have an influence on the financing choices of SMEs.

From the literature review, it has been summarised that there are ample studies exploring financing choices of firms and capital structure planning, but very few studies have been specifically related to SMEs. Moreover, most of the studies are conducted in developed countries. As per Dalberg (2011), SME financing continues to remain an under-researched area especially in developing economies. Focussing on India, it is observed that there is an increasingly growing interest among researchers on SMEs, and many studies have also been conducted on them, but most of these studies have focussed on financing choices of SMEs. There is a dearth of literature on SME listing and its implications on various aspects of SME financing. Hence, this study will add to the extant literature on SMEs by attempting to examine the impact of listing on the financing patterns of SMEs and to find out if only established firm-specific factors have a bearing on the financing choices or there are some other influential factors also.

\section{Method}

A detailed methodology of this study, starting from an explanation of variables to the discussions of tools and techniques used, is explained in this section.

\section{Research Design}

This study is done in an Indian context by including the companies listed on NSE Emerge exchange. This platform was incorporated in 2012 as SME exchange by National Stock Exchange (NSE) to assist small emerging companies to raise external capital. In 2019, there were 149 companies listed on this platform. Financial companies have been excluded from the study as the calculations and interpretations of their ratios are quite different from their non-financial counterparts. Further, in non-financial firms also only those are considered for which the data is available for the whole duration of the study i.e. between 2014 and 2018 (five years). After performing the data cleaning, 113 firms are selected, out of which 93 of them are involved in manufacturing activities while the rest are in service-rendering business.

Based on the detailed literature review, various internal factors that have an impact on the financial pattern of the SMEs are identified. The financial data related to selected sample companies is collected from ACE equity database. It is an updated corporate database that provides financial and non-financial information of Indian companies. For analysis, the balance panel data method has been used by applying both fixed and random effect models.

\section{Description of Variables and Framing of Hypotheses}

This study takes leverage as the dependent variable as it is the major factor in judging the financing pattern of the companies. Leverage (debt) can be broadly divided into two categories based on their maturity: short-term and longterm. The research on dependence of SMEs on short-term or long-term debt are inconclusive. Rao et al. (2018) concluded during their study that the major source of finance for SMEs is short-term in nature while Kumar (2014) found otherwise. This study calculates leverage in two different ways:

\section{Dependent Variables}

Leverage $_{1}=$ Total Debt $/$ Total Assets. The ratio measuring leverage ${ }_{1}$ shows the amount of external debt used by the company to purchase its assets. It considers the overall company's debt (short-term as well as long-term) and not only long-term borrowings in the form of loans, bonds and debentures among others (Cassar \& Holmes, 2003; Chakraborty, 2010).

Leverage $_{2}=$ Short-term Debt $/$ Total Assets. As concluded in many previous studies (Cassar \& Holmes, 2003), short-term debt is the major source of finance for SMEs. Hence, this ratio is an important measure of leverage in the study on SMEs.

\section{Independent Variables}

Liquidity. SMEs mostly depend on more liquid shortterm financing i.e. current liabilities (Kaur \& Rao, 2009; Moosa et al., 2011; Singhania \& Seth, 2010). Current Ratio is used to measure liquidity of SMEs. New and growing SMEs maintain higher liquidity and do not rely more on borrowings. Therefore, the first hypothesis of the study is:

H1. Liquidity and leverage are inversely related.

Non-Debt Tax Shield. It is measured by dividing the amount of depreciation by total assets. Huang \& Song (2006) observed during their study that companies prefer debt financing as the cost of this finance gives tax advantage. Hence, the hypothesis made is: 
H2. There is a negative relationship between Non-Debt Tax Shield and leverage.

Size of the Firm. Khan (2010) concluded during their study that the greater the size of the firm, the easier the availability of external financial support and that too at lower cost. In literature, it was found that the size is measured either with the help of sales of the entity, assets possessed by the same or market capitalization (in case of listed companies) (Khan, 2010; Rao et al., 2018). Here, it is measured with the help of a $\log$ of sales. Generally, $\log$ is taken to reduce the effects of outliers in the data. The hypothesis made for this variable is:

H3. There is positive relationship between the size of the firm and leverage.

Tangibility. The tangible assets possessed by the firms can be used as collateral to raise external financing. These assets are valued by the lender before it grants credit to the borrower (Huang \& Song, 2006; Khan, 2010). The proportion of tangible fixed assets a firm possesses, vis-a-vis its total assets is a ratio that measures tangibility of the firm. So, the hypothesis is:

H4. Tangibility and leverage are positively related.

Profitability. It can be expressed in two ways:

Operating Income (Prof). It is the ratio of profit before depreciation, interest and tax to total assets. Over the years, profitability is mostly studied with the help of operating income ratio (Bhaduri, 2002; Khan, 2010). It is believed that SMEs rely more on internal resources and profitability is a major contributor of internal funds.

H5. Profitability measured in terms of operating income and leverage are negatively related.

Return on Equity (ROE). It is a relatively less studied variable in the study on SME financing (Madan, 2007; Rao et al., 2018). Pecking Order hypothesis may explain the relationship between the ROE and leverage. The firm would prefer to use retained earnings in the situation of asymmetric information.

H6. There is a negative relationship between ROE and leverage.

Cash Flows. According to Mateeva et al. (2013), the higher the cash flows, the lower the need for borrowings for a business. To calculate the cash flows ratio, depreciation and profit after tax are added and then the sum of the two is divided by the total assets. The hypothesis related to cash flows is:

H7. There is a negative relationship between cash flows of the firm and leverage.

Table 1 shows the list of variables and some of the literature using these variables:

Table 1

Summary of variables

\begin{tabular}{|c|c|}
\hline Variables Chosen & $\begin{array}{c}\text { Existing Literature using } \\
\text { these Variables }\end{array}$ \\
\hline $\begin{array}{l}\text { Dependent Variable: } \\
\text { Leverage }_{1}\end{array}$ & $\begin{array}{l}\text { Cassar \& Holmes (2003); } \\
\text { Chakraborty (2010) }\end{array}$ \\
\hline $\begin{array}{l}\text { Dependent Variable: } \\
\text { Leverage }_{2}\end{array}$ & Cassar \& Holmes (2003) \\
\hline $\begin{array}{l}\text { Independent Variable: } \\
\text { Liquidity }\end{array}$ & $\begin{array}{l}\text { Kaur \& Rao (2009); Singha- } \\
\text { nia \& Seth (2010); Moosa et } \\
\text { al. (2011) }\end{array}$ \\
\hline $\begin{array}{l}\text { Independent Variable: } \\
\text { Non-Debt Tax Shield }\end{array}$ & Huang \& Song (2006) \\
\hline $\begin{array}{l}\text { Independent Variable: } \\
\text { Size of the firm }\end{array}$ & $\begin{array}{l}\text { Khan (2010); Rao et al. } \\
\text { (2018) }\end{array}$ \\
\hline $\begin{array}{l}\text { Independent Variable: } \\
\text { Tangibility }\end{array}$ & $\begin{array}{l}\text { Huang \& Song (2006); Khan } \\
\text { (2010) }\end{array}$ \\
\hline $\begin{array}{l}\text { Independent Variable: } \\
\text { Profitability }\end{array}$ & Bhaduri (2002); Khan (2010) \\
\hline $\begin{array}{l}\text { Independent Variable: } \\
\text { ROE }\end{array}$ & $\begin{array}{l}\text { Madan (2007); Rao et al. } \\
\text { (2018) }\end{array}$ \\
\hline $\begin{array}{l}\text { Independent Variable: } \\
\text { Cash Flows }\end{array}$ & Mateeva et al. (2013) \\
\hline
\end{tabular}

Source: Authors' compilation

Table 2 summarizes the implications of the TOT, POT and that of few empirical evidences from existing literature about the relationship between leverage and the chosen independent variables.

\section{Proposed Models}

Based on above identified variables and their relationship with dependent variables, the following two models have been proposed for further analysis: 
Table 2

Relationship between explanatory and explained variables as per TOT and POT

\begin{tabular}{|c|c|c|}
\hline $\begin{array}{l}\text { Independent } \\
\text { Variables }\end{array}$ & $\begin{array}{l}\text { Relationship with } \\
\text { Leverage as per } \\
\text { Trade-Off Theory } \\
\text { (TOT) }\end{array}$ & $\begin{array}{l}\text { Relationship with } \\
\text { Leverage as per } \\
\text { Pecking Order } \\
\text { Theory (POT) }\end{array}$ \\
\hline Liquidity & $\begin{array}{l}\text { (+) Long \& Malitz } \\
(1985)\end{array}$ & $\begin{array}{l}\text { (-) Griner \& Gordon } \\
\text { (1995); Singhania } \\
\text { \& Seth }(2010)\end{array}$ \\
\hline $\begin{array}{l}\text { Non-Debt } \\
\text { Tax Shield }\end{array}$ & $\begin{array}{l}(+) \text { Bradley et al. } \\
(1984)\end{array}$ & $\begin{array}{l}\text { (-) Huang \& Song } \\
\text { (2004); Griner \& } \\
\text { Gordon (1995) }\end{array}$ \\
\hline $\begin{array}{l}\text { Size of the } \\
\text { Firm }\end{array}$ & $\begin{array}{l}\text { (+) Chittenden } \\
\text { (1996); Huang \& } \\
\text { Song (2004); Khan } \\
\text { (2010) ; Singhania } \\
\text { \& Seth (2010) }\end{array}$ & $\begin{array}{l}\text { (-) Rajan \& Zinga- } \\
\text { les (1995) ; Titman } \\
\text { \& Wessels (1988) }\end{array}$ \\
\hline Tangibility & $\begin{array}{l}\text { (+) Dammon \& } \\
\text { Senbet }(1988) ; \\
\text { Khan }(2010)\end{array}$ & $\begin{array}{l}\text { (-) Huang \& Song } \\
\text { (2004); Lang et al. } \\
\text { (1996) }\end{array}$ \\
\hline Profitability & $\begin{array}{l}(+) \text { Givoly et al. } \\
(1992) \text {; Petersen \& } \\
\text { Rajan (1994) }\end{array}$ & $\begin{array}{l}\text { (-) Booth et al. } \\
(2001) ; \text { Khan } \\
\text { (2010); Shyam- } \\
\text {-Sunder \& Myers } \\
\text { (1999). }\end{array}$ \\
\hline ROE & $\begin{array}{l}\text { (+) Dammon \& } \\
\text { Senbet (1988); Gi- } \\
\text { voly et al. (1992) }\end{array}$ & $\begin{array}{l}\text { (-) Khan (2010); } \\
\text { Murinde et al. } \\
\text { (2004); Shyam-Sun- } \\
\text { der \& Myers(1999). }\end{array}$ \\
\hline Cash Flows & $\begin{array}{l}(+) \text { Dammon \& } \\
\text { Senbet }(1988)\end{array}$ & (-) Kester (1986) \\
\hline
\end{tabular}

Source: Authors' compilation

\section{Model 1}

$$
\begin{gathered}
\mathrm{LEV}_{1 \mathrm{it}}=\alpha_{\mathrm{i}}+\beta_{1} \mathrm{LIQ}_{\mathrm{it}}+\beta_{2} \mathrm{NDTS}_{\mathrm{it}}+\beta_{3} \mathrm{SIZE}_{\mathrm{it}}+\beta_{4} \mathrm{TANG}_{\mathrm{it}}+ \\
\beta_{5} \mathrm{PROF}_{\mathrm{it}}+\beta_{6} \mathrm{ROE}_{\mathrm{it}}+\beta_{7} \mathrm{CF}_{\mathrm{it}}+\varepsilon_{\mathrm{it}}
\end{gathered}
$$

\section{Model 2}

$$
\begin{gathered}
\mathrm{LEV}_{2 \mathrm{it}}=\alpha_{\mathrm{i}}+\beta_{1} \mathrm{LIQ}_{\mathrm{it}}+\beta_{2} \mathrm{NDTS}_{\mathrm{it}}+\beta_{3} \mathrm{SIZE}_{\mathrm{it}}+\beta_{4} \mathrm{TANG}_{\mathrm{it}}+ \\
\beta_{5} \mathrm{PROF}_{\mathrm{it}}+\beta_{6} \mathrm{ROE}_{2 \mathrm{it}}+\beta_{7} \mathrm{CF}_{\mathrm{it}}+\varepsilon_{\mathrm{it}}
\end{gathered}
$$

where,

$\mathrm{LEV}_{\text {it }}=$ Leverage of $i$-th $\quad$ PROF $=$ Operating Income firm at time $\mathrm{t}$

$$
\begin{array}{ll}
\text { TANG }=\text { Tangibility } & \text { NDTS }=\text { Non-Debt Tax Shield } \\
\text { LIQ = Liquidity } & \text { CF }=\text { Cash Flows } \\
\text { ROE = Return on Equity } & \alpha_{\mathrm{i}}=\text { Intercept } \\
\text { cit }=\text { Error term } &
\end{array}
$$

\section{Tools and Techniques}

For statistical analysis of data, Statistical Package for Social Sciences (SPSS) and Stata have been used. A multiple regression model for panel data is used for empirical analysis. OLS, fixed effect and random effect models have been used for the study.

\section{Results}

As seen in Table 3, a decreasing trend has been observed for both the leverage ratios throughout the period of the study. It may be due to an increase in number of listed companies resulting in increased equity capital. It also shows that debt has not increased in the same proportion. It is very much in line with the existing literature about SMEs' lesser usage of debt financing and external borrowings (Kumar \& Rao, 2016).

Table 3

Mean values of overall, long-term and short-term debt to total asset

\begin{tabular}{lccccc}
\hline & $\mathbf{2 0 1 4}$ & $\mathbf{2 0 1 5}$ & $\mathbf{2 0 1 6}$ & $\mathbf{2 0 1 7}$ & $\mathbf{2 0 1 8}$ \\
\hline LTD/TA & 0.15 & 0.13 & 0.12 & 0.11 & 0.09 \\
STD/TA & 0.23 & 0.23 & 0.21 & 0.17 & 0.10 \\
TD/TA & 0.38 & 0.36 & 0.33 & 0.28 & 0.19 \\
\hline
\end{tabular}

Source: Authors' calculation

The trend of SME financing across various sources of funds in India is illustrated in Figure 1. It can be observed that current liabilities, total reserves and short-term borrowings are the most preferred sources of finance by SMEs. The listed SMEs depend significantly on current liabilities as it can be easily created. For further requirement of funds, they opt for retained earnings accumulated in the form of reserves. Retained earnings are the major internal source of finance available without much effort. Then after, they opt for short-term borrowings. Usually, SMEs do not prefer to raise funds via issue of equity shares as it is a costly and time-consuming affair. Hence, share capital is seen at a 


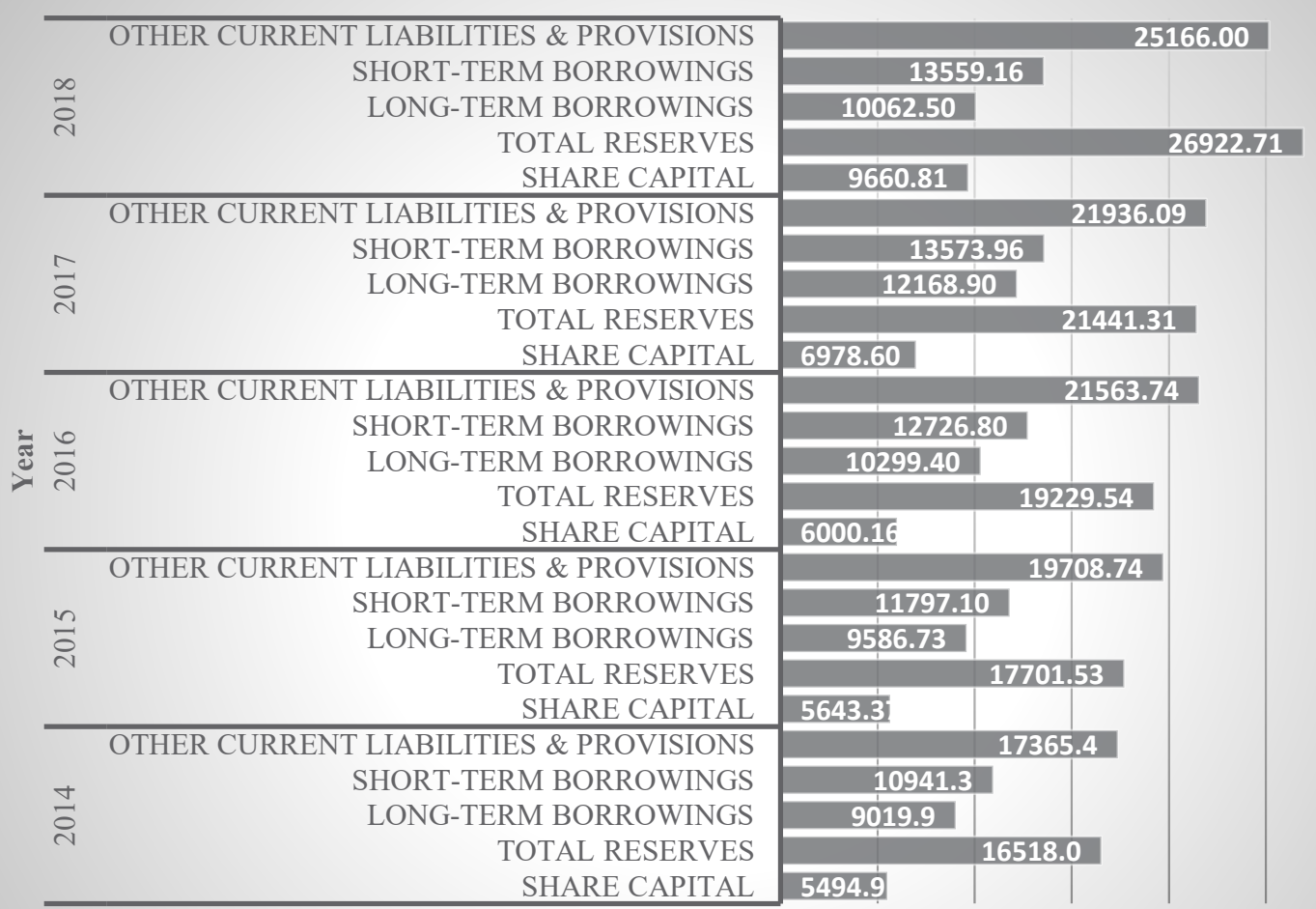

$\begin{array}{lll}0.0 & 5000.010000 .015000 .020000 .025000 .030000 .0\end{array}$

INR in Million

Figure 1. Sources of Finance in SMEs in India

Source: Based on the data collected from ACE Equity

steady level throughout the period of the study. In the last year, the level of share capital increased significantly due to a rise in the number of listed SMEs. Long-term borrowings are also not found to be at a very low level. Therefore, it can be inferred that SMEs may opt for it during their expansion phase to have some tax advantage.

The further discussion in this section is on statistical analysis of data. Descriptive statistics of the selected variables are presented in Table 4 . The total number of observations are 565 as the study is conducted on 113 firms for the period of five years. Smaller mean values of both leverages indicate lesser use of debt by the SMEs. This is in accordance with existing literature (Srinivas, 2013). It can be inferred from the mean values of both the dependent variables that SMEs rely more on short-term borrowings. This also supports existing literature (Kumar \& Rao, 2016; Odit \& Gobardhun, 2011). The value of standard deviation is higher in case of leverage ${ }_{2}$ as compared to leverage . This $^{\text {Th }}$ indicates a higher degree of fluctuations in the ratio of shortterm debt to total assets across companies and time.

The correlation matrix of the explained and corresponding explanatory variables is depicted in Table 5. A high correlation of 0.812 is found between cash flows and operating income. The ROE is also strongly correlated with the cash flows and operating income. Again, a high posi-
Table 4

Descriptive statistics

\begin{tabular}{lcccc}
\hline Variables & Mean & Median & $\begin{array}{c}\text { Std. } \\
\text { Deviation }\end{array}$ & Observations \\
\hline LEV1 & 0.31 & 0.51 & 0.24 & 565 \\
LEV2 & 0.20 & 0.33 & 1.08 & 565 \\
LIQ & 1.81 & 1.29 & 1.79 & 565 \\
NDTS & 0.07 & 0.05 & 0.08 & 565 \\
SIZE & 3.70 & 3.79 & 1.19 & 565 \\
TANG & 0.49 & 0.44 & 0.45 & 565 \\
PROF & & & & \\
(Op & 0.33 & 0.27 & 0.21 & 565 \\
Income) & & & & \\
ROE & 0.20 & 0.15 & 0.24 & 565 \\
CF & 0.17 & 0.14 & 0.15 & 565 \\
\hline
\end{tabular}

Source: Authors' calculation

tive relationship is observed between cash flows and NDTS. One of the major limitations of multiple regression analysis is the problem of multicollinearity when a high degree of correlation is witnessed between independent variables.

In both the models, the test of Variance Inflation Factor (VIF) has been conducted to verify the problem of multi- 
Table 5

Pearson correlation matrix

\begin{tabular}{|c|c|c|c|c|c|c|c|c|c|c|}
\hline & $\mathbf{L E V}_{1}$ & $\mathbf{L E V}_{2}$ & LIQ & NDTS & SIZE & TANG & $\begin{array}{c}\operatorname{PROF}(\mathrm{Op} \\
\text { Income) }\end{array}$ & ROE & $\mathbf{C F}$ & VIF \\
\hline LEV1 & 1 & & & & & & & & & \\
\hline LEV2 & 0.059 & 1 & & & & & & & & \\
\hline LIQ & $-0.209 * *$ & $-0.147 * *$ & 1 & & & & & & & 1.188 \\
\hline NDTS & 0.069 & 0.044 & $-0.170 * *$ & 1 & & & & & & 3.639 \\
\hline SIZE & -0.075 & -0.033 & $-0.185 * *$ & -0.025 & 1 & & & & & 1.066 \\
\hline TANG & $0.213 * *$ & $0.172 * *$ & $-0.251 * *$ & $0.388 * *$ & -0.015 & 1 & & & & 1.262 \\
\hline $\begin{array}{l}\text { PROF } \\
\text { (Op } \\
\text { Income) }\end{array}$ & $-0.170 * *$ & $0.375^{* *}$ & $-0.156^{* *}$ & $0.548 * *$ & $0.102 *$ & $0.288^{* *}$ & 1 & & & 7.188 \\
\hline ROE & -0.053 & $0.371 * *$ & -0.035 & $0.157 * *$ & 0.052 & $0.181 * *$ & $0.739 * *$ & 1 & & 3.968 \\
\hline CF & $-0.227 * *$ & $0.177 * *$ & -0.075 & $0.671 * *$ & 0.034 & $0.304 * *$ & $0.812^{* *}$ & $0.731 * *$ & 1 & 7.618 \\
\hline
\end{tabular}

Source: Authors' calculations

Note: ** At $90 \%$ level of significance; * At $95 \%$ level of significance.

collinearity. The value of VIF, as shown in Table 5, for operating income, ROE, NDTS and cash flows variables are less than 10 (Neter et al., 1996), and so these variables have been considered to be a part of these models.

According to Wansbeek (1992), as panel data considers time dimension, an autocorrelation problem often occurs between the residuals of the same units. This study used the Durbin-Watson test to identify if this problem persists here. The test statistics for Model 1 and 2 are 1.71 and 1.54 respectively, and it is within the accepted range (Gujarati, 2009).

\section{Analysis of Model 1}

To interpret the results of panel data regression, the paper analysed each model separately. Coefficients for OLS, fixed effects and random effects for Model 1 are estimated and presented in Table 6. Pooled OLS ideally should be employed when different samples are observed for each period of panel data (Wooldridge, 2010). Furthermore, as various assumptions of pooled OLS were rejected, the study focused on the results of fixed and random effect models. The Hausman test was performed to identify which model is likely to be the best estimate for the current study.

It is inferred from the values in Table 5 that the variables viz. liquidity, size and cash flows are inversely related to leverage in Model 1. Similarly, the operating income, ROE, tangibility and non-debt tax shield are positively related to leverage. For Model 1, it can be observed that all variables, except for liquidity and tangibility, are significant at $95 \%$ confidence level.
Table 6

Coefficients for OLS, fixed effects and random effects for Model 1

\begin{tabular}{|c|c|c|c|}
\hline \multirow[t]{2}{*}{ Variables } & $\begin{array}{l}\text { (Pooled } \\
\text { OLS) }\end{array}$ & $\begin{array}{l}\text { (Fixed } \\
\text { Effects) }\end{array}$ & $\begin{array}{l}\text { (Random } \\
\text { Effects) }\end{array}$ \\
\hline & TDTA & TDTA & TDTA \\
\hline \multirow{2}{*}{ LIQ } & $-0.012 * * *$ & -0.003 & $-0.008^{*}$ \\
\hline & $(0.005)$ & $(0.004)$ & $(0.004)$ \\
\hline \multirow{2}{*}{ ROE } & $0.009 * * *$ & $0.005 * * *$ & $0.006 * * *$ \\
\hline & $(0.001)$ & $(0.001)$ & $(0.001)$ \\
\hline \multirow{2}{*}{ TANG } & $0.109 * * *$ & 0.030 & $0.106^{* * *}$ \\
\hline & $(0.026)$ & $(0.034)$ & $(0.028)$ \\
\hline \multirow{2}{*}{ SIZE } & $-0.014 * *$ & $-0.092 * * *$ & $-0.040 * * *$ \\
\hline & $(0.006)$ & $(0.012)$ & $(0.008)$ \\
\hline \multirow{2}{*}{ NDTS } & $2.292 * * *$ & $1.461 * * *$ & $1.685 * * *$ \\
\hline & $(0.187)$ & $(0.205)$ & $(0.183)$ \\
\hline \multirow{2}{*}{$\begin{array}{l}\text { PROF } \\
\text { (Op Income) }\end{array}$} & $0.205 * *$ & $0.202 *$ & $0.251 * *$ \\
\hline & $(0.097)$ & $(0.120)$ & $(0.103)$ \\
\hline \multirow{2}{*}{$\mathbf{C F}$} & $-2.534 * * *$ & $-1.653 * * *$ & $-2.020 * * *$ \\
\hline & $(0.185)$ & $(0.203)$ & $(0.184)$ \\
\hline \multirow{2}{*}{ Constant } & $0.385^{* * *}$ & $0.671 * * *$ & $0.468 * * *$ \\
\hline & $(0.033)$ & $(0.050)$ & $(0.038)$ \\
\hline Observations & 565 & 565 & 565 \\
\hline$R^{2}$ & 0.419 & 0.344 & \\
\hline $\begin{array}{l}\text { No. of } \\
\text { Companies }\end{array}$ & & 113 & 113 \\
\hline
\end{tabular}

Source: Authors' calculation

Note: Standard errors in parentheses. $* * * p<0.01$, 95 
From the results of the Hausman test (Table 7), it is inferred that a null hypothesis which states no correlation between individual effects is rejected. Therefore, in this study, the fixed-effect model is the best estimate.

Table 7

Hausman fixed random

\section{Coefficients}

\begin{tabular}{lcccc} 
& $\begin{array}{c}(\mathbf{b}) \\
\text { Fixed }\end{array}$ & $\begin{array}{c}(\mathbf{B}) \\
\text { Random }\end{array}$ & $\begin{array}{c}(\mathbf{b}-\mathbf{B}) \\
\text { Sqrt } \\
\text { Difference }\end{array}$ & $\begin{array}{c}(\text { Diag } \\
(\mathbf{V}-\mathbf{b}-\mathbf{S} \text { S.E. }\end{array}$ \\
\hline LIQ & -0.0034 & -0.0075 & 0.0042 & \\
NDTS & 1.4605 & 1.6847 & -0.2241 & 0.0918 \\
SIZE & -0.0924 & -0.0401 & -0.0523 & 0.0084 \\
TANG & 0.03044 & 0.1062 & -0.0757 & 0.0196 \\
PROF & 0.2017 & 0.2510 & -0.0492 & 0.0620 \\
(Op & & & & \\
Income) & & & & \\
ROE & 0.0050 & 0.0057 & -0.0007 & 0.0001 \\
CF & -1.6533 & -2.0203 & 0.3670 & 0.0861 \\
\hline
\end{tabular}

Source: Authors' calculation

Note: $\mathrm{b}=$ consistent under $\mathrm{H}_{0}$ and $\mathrm{H}_{\mathrm{a}}$; obtained from xtreg; $\mathrm{B}=$ inconsistent under $\mathrm{H}_{\mathrm{a}}$, efficient under $\mathrm{H}_{0}$; obtained from xtreg.

Test: $\mathrm{H}_{0}$ : difference in coefficients not systematic $\operatorname{chi}^{2}(7)=(b-B)^{\prime}\left[\left(\mathrm{V} b-\mathrm{V} \_\mathrm{B}\right)^{\wedge}(-1)\right](\mathrm{b}-\mathrm{B})=333.18$

Prob $>$ chi $^{2}=0.0000$

(V_b-V_B is not positive definite)

Since in Table 6, $R$-squared value is 0.344 , it implies that the independent variables only explain $34.4 \%$ engagement in the explained variable (here, Leverage ${ }_{1}$ ). In this study, leverage is explained as the ratio of total debt to total assets.

\section{Analysis of Model 2}

For Model 2, it can be concluded from the signs of coefficients and t-values for each independent variable in Table 8 that liquidity, cash flows and size are negatively related to the leverage. Whereas profitability, ROE, tangibility and non-debt tax shield are positively related to the dependent variable. All the variables are significant at 95\% confidence level, except liquidity.

Another important inference from Table 8 is the $R$-squared value of $45.9 \%$, which is slightly higher compared to the $R$-squared value in Model 1 (Table 8). It indicates that the explanatory variables in Model 2 have more power to explain the dependent variable - short-term debt
Table 8

Coefficients for OLS, fixed effects and random effects for Model 2

\begin{tabular}{|c|c|c|c|}
\hline Variables & $\begin{array}{c}\text { Pooled } \\
\text { OLS } \\
\text { STDTA }\end{array}$ & $\begin{array}{c}\text { Fixed Effect } \\
\text { STDTA }\end{array}$ & $\begin{array}{c}\text { Random } \\
\text { Effect } \\
\text { STDTA }\end{array}$ \\
\hline LIQ & $\begin{array}{l}-0.003 \\
(0.021)\end{array}$ & $\begin{array}{l}-0.007 \\
(0.021)\end{array}$ & $\begin{array}{l}-0.009 \\
(0.019)\end{array}$ \\
\hline ROE & $\begin{array}{c}0.028 * * * \\
(0.003)\end{array}$ & $\begin{array}{c}0.029 * * * \\
(0.003)\end{array}$ & $\begin{array}{c}0.028 * * * \\
(0.003)\end{array}$ \\
\hline TANG & $\begin{array}{c}0.175 * * \\
(0.087)\end{array}$ & $\begin{array}{c}0.234 * * \\
(0.104)\end{array}$ & $\begin{array}{c}0.266^{* * *} \\
(0.088)\end{array}$ \\
\hline SIZE & $\begin{array}{c}-0.111 * * * \\
(0.029)\end{array}$ & $\begin{array}{c}-0.284 * * * \\
(0.061)\end{array}$ & $\begin{array}{c}-0.157 * * * \\
(0.037)\end{array}$ \\
\hline NDTS & $\begin{array}{c}4.313 * * * \\
(0.799)\end{array}$ & $\begin{array}{c}5.037 * * * \\
(1.072)\end{array}$ & $\begin{array}{c}4.208 * * * \\
(0.846)\end{array}$ \\
\hline $\begin{array}{l}\text { PROF (Op } \\
\text { Income) }\end{array}$ & $\begin{array}{c}6.469 * * * \\
(0.447)\end{array}$ & $\begin{array}{c}5.716 * * * \\
(0.646)\end{array}$ & $\begin{array}{c}6.387 * * * \\
(0.500)\end{array}$ \\
\hline CF & $\begin{array}{c}-11.966 * * * \\
(0.837)\end{array}$ & $\begin{array}{c}-10.356^{* * *} \\
(1.085)\end{array}$ & $\begin{array}{c}-11.506 * * * \\
(0.885)\end{array}$ \\
\hline Constant & $\begin{array}{c}0.076 \\
(0.143)\end{array}$ & $\begin{array}{c}0.568 * * \\
(0.252)\end{array}$ & $\begin{array}{c}0.161 \\
(0.171)\end{array}$ \\
\hline Observations & 565 & 565 & 565 \\
\hline$R^{2}$ & 0.426 & 0.459 & \\
\hline $\begin{array}{l}\text { No. of } \\
\text { Companies }\end{array}$ & & 113 & 113 \\
\hline
\end{tabular}

Source: Authors' calculation

Note: Standard errors in parentheses; $* * * p<0.01$, $* * p<0.05, * p<0.1$

to total assets ratio - Leverage .

Table 9 depicts the results of the Hausman test for Model 2. The null hypothesis states no correlation between individual effects. Observing the numbers in Table 9, the null hypothesis stands rejected, concluding that the fixed effect model is more relevant.

To summarise the results, it can be observed that SMEs are depending more on short-term liabilities as compared to long-term external liability (Figure 1). It also implies that listing is not giving any significant boost to SMEs in terms of debt financing. From the interpretations of statistical models, it is concluded that the explanatory power of both the models is found to be low due to lower $R$-squared values (Table 6: 34.4\%: Model 1 and Table 8: 45.9\%: Model 2 ). The reason may be due to the impact of some external factors that are beyond the scope of existing study or some other firm-specific factors. 
Table 9

Hausman fixed random

\section{Coefficients}

\begin{tabular}{lcccc} 
& $\begin{array}{c}\text { (b) } \\
\text { Fixed }\end{array}$ & $\begin{array}{c}(\mathbf{B}) \\
\text { Random }\end{array}$ & $\begin{array}{c}\text { (b-B) } \\
\text { sqrt } \\
\text { Difference }\end{array}$ & $\begin{array}{c}(\mathbf{d i a g} \\
(\mathbf{V}-\mathbf{b}-\mathbf{V} \text {-E.E. }\end{array}$ \\
\hline LIQ & -0.0067 & -0.00925 & 0.0025 & 0.0203 \\
NDTS & 5.0365 & 1.8631 & 3.1735 & 1.0581 \\
SIZE & -0.2836 & -0.0431 & -0.2405 & 0.0608 \\
TANG & 0.2337 & 0.0432 & 0.1905 & 0.1028 \\
PROF & 5.7162 & 0.2868 & 5.4294 & 0.6382 \\
(Op & & & & \\
Income) & & & & \\
ROE & 0.02936 & 0.0060 & 0.0234 & 0.0032 \\
CF & -10.3559 & -2.1330 & -8.2229 & 1.0701 \\
\hline SOrce:
\end{tabular}

Source: Authors' Calculation

Note: $\mathrm{b}=$ consistent under Ho and $\mathrm{Ha}$; obtained from xtreg;

$\mathrm{B}=$ inconsistent under Ha, efficient under Ho; obtained from xtreg.

Test: $\mathrm{H}_{0}$ : difference in coefficients not systematic

$\mathrm{Chi}^{2}(7)=(\mathrm{b}-\mathrm{B})^{\prime}\left[\left(\mathrm{V} \_\mathrm{b}-\mathrm{V} \_\mathrm{B}\right)^{\wedge}(-1)\right](\mathrm{b}-\mathrm{B})=358.13$

Prob $>$ chi $^{2}=0.0000$

\section{Discussion and Validation of Hypotheses}

This study intends to examine the influence of selected firm-specific factors on the financing pattern of the listed SMEs in India. It considers leverage as explained variable and liquidity, tangibility, size, profitability, ROE, cash flows and non-debt tax shield as explanatory variables for statistical analysis. The summary of the outcomes of the hypotheses formulated and tested to evaluate the relationships among selected variables and the applicability of TOT and POT based on the results obtained are presented in Table 10.

Non-debt tax shields and tangibility are positively related to financial leverage as concluded from the statistical analysis, and it is in line with Trade-Off Theory. On the other hand, cash flows, operating income and ROE are negatively related with the dependent variable, which is in favour of POT. Hence, no single theory of finance is found to be capable of explaining SME financing behaviour completely.

\section{Limitations and Future Scope}

Every research is subject to certain limitations and so is this study. In this section, shortcomings and future scope of the present study have been discussed. First limitation is

Table 10

Summary results of hypotheses

\begin{tabular}{|c|c|c|c|c|c|}
\hline No. & Hypotheses & Model 1 & Model 2 & TOT & POT \\
\hline 1. & $\mathbf{H}_{1}$. Liquidity and leverage are inversely related. & $(\mathrm{NS})$ & (NS) & $(-)$ & $(+)$ \\
\hline 2. & $\begin{array}{l}\mathbf{H}_{2 .} \text {. There is a negative relationship between Non-Debt Tax } \\
\text { Shield and leverage. }\end{array}$ & Rejected $^{* * *}$ & Rejected $^{* * *}$ & $(+)$ & $(-)$ \\
\hline 3. & $\begin{array}{l}\mathbf{H}_{3} \text {. There is positive relationship between the size of the } \\
\text { firm and leverage. }\end{array}$ & Rejected $^{* * *}$ & Rejected $^{*}$ & $(-)$ & $(-)$ \\
\hline 4. & $\mathbf{H}_{4}$. Tangibility and leverage are positively related. & (NS) & Accepted $^{* * *}$ & $(+)$ & $(-)$ \\
\hline 5. & $\begin{array}{l}\mathbf{H}_{5^{.}} \text {Profitability measured in terms of Operating income } \\
\text { and leverage are negatively related. }\end{array}$ & Rejected* & Rejected $^{* * *}$ & $(+)$ & $(-)$ \\
\hline 6. & $\begin{array}{l}\mathbf{H}_{6} \text {. There is a negative relationship between ROE and } \\
\text { leverage. }\end{array}$ & Rejected $^{* * *}$ & Rejected $^{* * *}$ & $(+)$ & $(-)$ \\
\hline 7. & $\begin{array}{l}\mathbf{H}_{7^{\circ}} \text { There is a negative relationship between cash flows of } \\
\text { the firms and leverage. }\end{array}$ & Accepted $^{* * *}$ & Accepted $^{* * *}$ & $(-)$ & $(+)$ \\
\hline
\end{tabular}

Note: NS: Not Significant ${ }^{*}$ significant at $90 \%$ confidence level; ${ }^{* *}$ significant at $95 \%$ confidence level; ${ }^{* * *}$ significant at $99 \%$ confidence level. 
the availability of data. For some SMEs, it is available for a shorter duration post listing while for others, it is available for a longer duration. Second, obtaining the authentic SME data through a secondary source is a challenge. Third, the sample includes only those SMEs which are listed on NSE Emerge exchange, so, the outcomes of the study may not be generalisable.

The limitations of the study provide the scope for future research. Similar study can be conducted with a larger sample size with an increase in the listing of SMEs over time. India is a bank dominated economy. Difficulty in raising debt finance in such an economy needs to be studied further in detail. Apart from that, declining debt-equity ratio in the capital structure of SMEs despite having tax advantage demands detailed investigation. Further, to improve the explanatory power of the models, some more firm-specific as well as external variables can be explored which may affect the financing choices of SMEs. External factors may include government initiatives for SMEs or some macroeconomic factors like interest rates and inflation, which impact the capital structure of any business.

\section{Concluding Remarks}

The study attempts to examine the key factors having influence on the financing pattern of the SMEs listed on NSE Emerge exchange in India. In other words, the study contributes to the extant literature on listed SMEs by attempting to examine the impact of listing on the financing patterns of SMEs and to find out if only established firm-specific factors have a bearing on the financing choices or there are some other influential factors also. Here, the leverage has been calculated in two ways: (a) Total Debt/Total Asset and (b) Short-term Debt/Total Asset. Among the independent variables chosen based on an extensive literature survey, most of them, like tangibility, size, NDTS, operating income, ROE and cash flows, are statistically significant, but the small values of $R$-squared in both the models depict lower explanatory power of independent variables to predict the dependent variables. This is in contrast with various previous studies conducted on SMEs (Chakraborty, 2010; Mateeva et al., 2013; Rao et al., 2018). It suggests that there may be some other firm-specific factors or macroeconomic factors that influence the listed firms' financing choice.

Debt is considered to be the least preferred source of SME finance. Srinivas (2013) and Kumar \& Rao (2016) encountered the opposite conclusions during their study though on non-listed SMEs. In a bank dominated economy like India, difficulty in raising debt finance needs to be studied further in detail. Several studies have suggested that difficulty in raising finance for SMEs may be due to lack of proper book-keeping and non-availability of audited financial results (Liu \& Yu, 2008; Storey, 1994). As the present study considers only the listed SMEs and they get their financial statements audited regularly, hence it is expected that these firms have high creditworthiness in the market. Despite having tax advantage, their declining debt-equity ratio demands detailed investigation.

The study also concludes no single theory of finance is found to be capable of explaining SME financing behaviour completely. As per Serrasqueiro \& Nunes (2012), POT and TOT cannot be considered to be mutually exclusive. As per them, these theories should be studied independently with reference to SMEs.

Lesser use of debt finance by the listed SMEs is the issue worth investigating in India if it is due to unavailability of funds for them. If it is so, the situation of the unorganized SMEs can be easily understandable. Ultimately, it raises the questions about the quality and fundamentals of companies listed or to be listed and the success behind SME exchanges. Thus, the present study strongly feels the urge to identify other firm-specific variables and macroeconomic factors to explain the financing decision of listed SMEs. It also concludes that listing does not give any significant boost to SMEs in terms of debt financing.

\section{References}

Abdulsaleh, A. M. A. (2015). Bank financing for small and medium-sized enterprises (SMEs) in Libya. Thesis, Department of Accounting, Finance and Economics Griffith Business School Griffith University. www. hdl.handle.net.

Abe, M., Troilo, M., \& Batsaikhan, O. (2015). Financing small and medium enterprises in Asia and the Pacific. Journal of Entrepreneurship and Public Policy, 4(1), 2-32.

Adeyele, J. S. (2018). Financial institutions' criteria and mechanisms in financing small and medium enterprises in plateau state, Nigeria. Ekonomski Horizonti, Maj - Avgust, 20(2), 109-125.doi:10.5937/ekonhor1802109a.

Ambrose, J. (2012). Venture Capital (VC): The all important MSMEs financing strategy under neglect in Kenya. International Journal of Business and Social Science, 3(21), 234-240.

Ariyo, D. (2000). Small firms are the backbone of the Nigerian economy. Africa Economic Analysis. http:// www.afbis.com/analysis/small.htm

Asare, A. O. (2014). Challenges affecting SMEs' growth in Ghana. OIDA International Journal of Sustainable Development, 07(6), 23-28. 
Baker, M. \& Wurgler, J. (2002). Market timing and capital structure. The Journal of Finance 57(1), 1-32.

Bas, T., Muradoglu, G., \& Phylaktis, K. (2009). Determinants of capital structure in developing countries. Research Paper Series. Cass Business School, London, UK.

Beck, T., Maimbo, S. M., Faye, I., \& Triki, T. (2011). Financing Africa: Through the crisis and beyond. The World Bank.

Beattie, V., Goodacre, A., \& Thomson, S. J. (2006). Corporate financing decisions: UK survey evidence. Journal of Business Finance and Accounting, 33(9-10), 1402-1434.

Benito, A. (2003). The capital structure decisions of firms: Is there a pecking order? Working Paper 0310, Banco de Espana, Madrid, Spain.

Bhaduri, S. N. (2002). Determinants of capital structure choice: A study of the Indian corporate sector. Applied Financial Economics, 12(9), 655-665.

Bhattacharjee, A., \& Dash, M. (2018). Determinants of capital structure in the Indian pharma sector. Journal of Applied Management and Investments, 7(3), 125-131.

Booth, L., Aivazian, V., Demirguc-Kunt, A. \& Maksimovic, V. (2001). Capital structures in developing countries. The Journal of Finance, 56(1), 87-130.

Bradley, M., Jarrell, G. A. \& Kim, E. (1984). On the existence of an optimal capital structure: Theory and evidence. The Journal of Finance, 39(3), 857-878.

Cassar, G., \& Holmes, S. (2003). Capital structure and financing of SMEs: Australian evidence. Accounting and Finance, 43(2), 123-147.

Chakraborty, I. (2010). Capital structure in an emerging stock market-case of India. Research in International Business and Finance, 24(3), 295-314.

Chittenden, F., Hall, G. \& Hutchinson, P. (1996). Small firm growth, access to capital markets and financial structure: Review of issues and an empirical investigation. Small Business Economics, 8, 59-67.

Dalberg, H. (2011). Report on support to SMEs in developing countries through financial intermediaries. Retrieved September 10, 2019, from http://www.acp. int/content/report-support-smes-developing-countries-through-financial-intermediaries

Dammon, R. M. \& Senbet, L. W. (1988). The effect of taxes and depreciation on corporate investment and financial leverage. The Journal of Finance, 43(2), 357373.

Daskalakis, N., \& Psillaki, M. (2008). Do country or firm factors explain capital structure? Evidence from SMEs in France and Greece. Applied Financial Eco- nomics, 18(2), 87-97.

Datta, D., \& Agarwal, B. (2009). Determinants of capital structure of Indian corporate sector in the period of bull run 2003-2007-An econometric study. SSRN. http://dx.doi.org/10.2139/ssrn.1376064

De, S. (2010). Financing Indian SMEs. ISBINSIGHT. Retrieved on August 15, 2020. http://isbinsight.isb.edu/ financing-smes-india/

Dogra, B. \& Gupta, S. (2009). An empirical study on capital structure of SMEs in Punjab. The IUP Journal of Applied Finance, 15(3), 60-80.

Fauzi F., Basyith A., \& Idris M. (2013). The determinants of capital structure: An empirical study of New Zealand-listed firms. Asian Journal of Finance and Accounting, 5(2), 1-21.

Givoly, D., Hayn, C., Ofer, A. R. \& Sarig, O. (1992). Taxes and capital structure: Evidence from firms' response to the Tax Reform Act of 1986. Review of Financial Studies, 5(2), 331-355.

Graham, J. R., \& Harvey, C. R. (2001). The theory and practice of corporate finance: Evidence from the field. Journal of Financial Economics, 60(2-3), 187243.

Green, C. J., Kirkpatrick, C. H., \& Murinde, V. (2006). Finance for small enterprise growth and poverty reduction in developing countries. Journal of International Development: The Journal of the Development Studies Association, 18(7), 1017-1030.

Griner, E. H. \& Gordon, L. A. (1995). Internal cash flow, insider ownership, and capital expenditures: A test of the pecking order and managerial hypotheses. Journal of Business Finance \& Accounting, 22(2), 179199.

Gujarati, D. N. (2009). Basic econometrics. Tata McGraw-Hill Education.

Handoo, A., \& Sharma, K. (2014). A study on determinants of capital structure in India. IIMB Management Review, 26(3), 170-182.

Hollenstein, H. (2005). Determinants of international activities: Are SMEs different? Small Business Economics, 24(5), 431-450.

Huang, S. G., \& Song, F. M. (2004). The determinants of capital structure: Evidence from China. China Economic Quarterly-Beijing, 3, 395-414

Jagoda, K., \& Herath, S. K. (2010). Acquisition of additional debt capital by small and medium enterprises (SMEs): Evidence from Canada. International Journal of Management and Enterprise Development, 8(2), 135-151.

Jensen, M. C. \& Meckling, W. H. (1976). Theory of the firm: Managerial behavior, agency costs and owner- 
ship structure. Journal of Financial Economics, 3(4), 305-360.

Kaur, R., \& Rao, N. K. (2009). Determinants of capital structure: Experience of Indian cotton textile industry. The XIMB Journal of Management, 6(2), 97-112.

Kester, W. C. (1986). Capital and ownership structure: A comparison of United States and Japanese manufacturing corporations. Financial Management, 15(1), 5-16.

Khan, Z. S. (2010). Determinants of capital structure: Case of listed paint manufacturing companies. Institute of Interdisciplinary Business Research, 2(6), 253-271.

Klapper, L. F., Sarria-Allende, V., \& Zaidi, R. (2006). A firm-level analysis of small and medium size enterprise financing in Poland. World Bank Policy Research Working Paper No 3984. The World Bank.

Kraus, A., \& Litzenberger, R. H. (1973). A state-preference model of optimal financial leverage. The Journal of Finance, 28(4), 911-922.

Kremp, E., Sauvé, A., \& Paranque, B. (1999). Corporate finance in Germany and France. Banque de France Bulletin Digest, 70, 19-41.

Kulkarni, P. \& Chirputkar, A.V. (2014). Impact of SME listing on capital structure decisions. Procedia Economics and Finance, 11, 431-444.

Kumar, N. S. (2014). A study on capital structure pattern of small and medium enterprises (SMEs). Journal of Economics and Finance, 5(6), 19-23.

Kumar, S., \& Rao, P. (2016). Financing patterns of SMEs in India during 2006 to 2013-An empirical analysis. Journal of Small Business and Entrepreneurship, 28(2), 97-131.

Lang, L., Ofek, E. \& Stulz, R. (1996). Leverage, investment, and firm growth. Journal of Financial Economics, 40(1), 3-29.

Liu, M., \& Yu, J. (2008). Financial structure, development of small and medium enterprises, and income distribution in the People's Republic of China. Asian Development Review, 25(1-2), 137-155.

Long, M. S., \& Malitz, I. B. (1985). Investment patterns and financial leverage. In B. Friedman (Ed.), Corporate capital structures in the United States (pp. 325-352). University of Chicago Press.

Love, I., \& Peria, M. S. M. (2005). Firm financing in India: Recent trends and patterns (Vol. 3476). World Bank Publications.

Lucey, B., Macan Bhaird, C., \& Vidal, J. S. (2016). Discouraged borrowers: Evidence for Eurozone SMEs. Working Paper. Trinity Business School.

Madan, K. (2007). An analysis of the debt-equity structure of leading hotel chains in India. International
Journal of Contemporary Hospitality Management, 19(5), 397-414.

Mateeva, M., Poutziouris, P. \& Ivanov, K. (2013). On the determinants of SME capital structure of Eastern and Central Europe-A dynamic panel analysis. International Business and Finance, 27(1), 28-51.

Michaelas, N., Chittenden, F., \& Poutziouris, P. (1999). Financial policy and capital structure choice in UK SMEs: Empirical evidence from company panel data. Small Business Economics, 12(2), 113-130.

Modigliani, F., \& Miller, M. H. (1958). The cost of capital, corporation finance and the theory of investment. The American Economic Review, 48(3), 261-297.

Moosa, I., Li, L., \& Naughton, T. (2011). Robust and fragile firm-specific determinants of the capital structure of Chinese firms. Applied Financial Economics, 21(18), 1331-1343.

Murinde, V., Agung, J. \& Mullineux, A. (2004). Patterns of corporate financing and financial system convergence in Europe. Review of International Economics, 12(4), 693-705

Myers, S. C. (1984). The capital structure puzzle. The Journal of Finance, 39(3), 574-592.

Myers, S. C., \& Majluf, N. S. (1984). Corporate financing and investment decisions when firms have information that investors do not have. Journal of Financial Economics, 13(2), 187-221.

Neter, J., Kutner, M. H., Nachtsheim, C. J., \& Wasserman, W. (1996). Applied linear statistical models. Irwin.

Odit, M. P., \& Gobardhun, Y. D. (2011). The determinants of financial leverage of SME's in Mauritius. International Business and Economics Research Journal, 10(3), 113-125.

OECD (2016). Financing SMEs and entrepreneurs 2016: An OECD scorecard. OECD Publishing. http://dx. doi.org/10.1787/fin_sme_ent-2016-en, pg. 27.

Osano, H. M., \& Languitone, H. (2016). Factors influencing access to finance by SMEs in Mozambique: Case of SMEs in Maputo central business district. Journal of Innovation and Entrepreneurship, 5(13), 1-16. doi: 10.1186/s13731-016-0041-0.

Petersen, M. A. \& Rajan, R. G. (1994). The benefits of lending relationships: Evidence from small business data. The Journal of Finance, 49, 3-37.

Pradhan, J. P., \& Sahu, P. P. (2008). Transnationalization of Indian Pharmaceutical SMEs. Bookwell Publisher.

Rajan, R. G. \& Zingales, L. (1995). What do we know about capital strucutre? Some Evidence from international data. The Journal of Finance, 50(5), 1421-1460.

Rao, P., Kumar, S., \& Madhavan, V. (2018). A study on factors driving the capital structure decisions of small 
and medium enterprises (SMEs) in India. IIMB Management Review, 31(1), 37-50.

Sánchez-Vidal, J., \& Martín-Ugedo, J. F. (2005). Financing preferences of Spanish firms: Evidence on the pecking order theory. Review of Quantitative Finance and Accounting, 25(4), 341-355.

Serrasqueiro, Z., \& Nunes, P. M. (2012). Is age a determinant of SMEs' financing decisions? Empirical evidence using panel data models. Entrepreneurship Theory and Practice, 36(4), 627-654.

Shikumo, D. H. \& Mwangi, M. (2016). Determinants of lending to small and medium enterprises by commercial banks in Kenya. Journal of Economics and Finance, 7(4), 57-63. doi: 10.9790/5933-0704045763.

Shyam-Sunder, L. \& Myers, S.C. (1999). Testing static tradeoff against pecking order models of capital structure. Journal of Financial Economics, 51(2), 219-244.

Singhania, M., \& Seth, A. (2010). Financial leverage and investment opportunities in India: An empirical study. International research Journal of Finance and Economics, 40(2), 215-226.

Sogorb-Mira, F. (2005). How SME uniqueness affects capital structure evidence from 1994- 1998. Small Business Economics, 25(5), 447-457.

Srinivas, K. T. (2013). Role of micro, small and medium enterprises in inclusive growth. International Journal of Engineering and Management Research (IJEMR), 3(4), 57-61.

Stevenson, H., \& Botzung, M. (2012). Why banks in emerging markets are increasingly providing non-financial services to small and medium enterprises. World Bank.

Storey, D. J. (1994). Understanding the Small Business Sector. International Thomson Business Press.

Titman, S., \& Wessels, R. (1988). The determinants of capital structure choice. The Journal of Finance, 43(1), 1-19.

Vasilescu, L. (2014). Accessing finance for innovative EU SMES key drivers and challenges. Economic Review - Journal of Economics and Business, 12(2), 35-47.

Wansbeek, T. (1992). Transformation for panel data when the disturbances are autocorrelated. Structural Change and Economic Dynamics, 3(2), 375-384.

Watson, R., \& Wilson, N. (2002). Small and medium size enterprise financing: A note on some of the empirical implications of a pecking order. Journal of Business Finance \& Accounting, 29(3-4), 557-578.

Woodridge, J. M. (2010). Econometric analysis of cross section and panel data (2nd edition). The MIT Press.

$\mathrm{Wu}$, J., Song, J., \& Zeng, C. (2008). An empirical evidence of small business financing in China. Management Research News, 31(12), 959-975.

Yartey, C. A. (2011). Small business finance in Sub-Saharan Africa: The case of Ghana. Management Research Review, 34(2), 172-185.

Yoshino, N. \& Taghizadeh-Hesary, F. (2018). The role of SMEs in Asia and their difficulties in accessing finance. Asian Development Bank Institute. http://hdl. handle.net/11540/9483

Zucchella, A. \& Palamara, G. (2006). Niche strategy and export performance. In A. Rialp \& J. Rialp (Eds.), International marketing research: Advances in international marketing, vol. 17 (pp. 63-87). https:// doi.org/10.1016/S1474-7979(06)17002-7 